\title{
VALIDATION OF TISSUE MICROARRAY FOR IMMUNOHISTOCHEMICAL ANALYSIS OF ORAL SQUAMOUS CELL CARCINOMA BY USING VIRTUAL CORES
}

Ramanathan A, Chong RM, Tay ZW, Siow-Wee C, Kallarakkal TG, Kassim NLA. Validation of Tissue Microarray for Immunohistochemical Analysis of Oral Squamous Cell Carcinoma by Using Virtual Cores. Annal Dent Univ Malaya 2014; 21(1)

\section{ABSTRACT}

Background: There is significant amount of research done on Oral Squamous cell carcinoma (OSCC). One research technique is immunohistochemical (IHC) analysis using whole sections. With little availability of OSCC tissues high throughput analysis such as Tissue Microarray (TMA) are capable of efficient analysis of small samples. However, the results become questionable if the tumor exhibits high degree of heterogeneity as TMA cores might not accurately represent the whole section. Aim: The aim of this study is to determine the optimal number of TMA cores required to provide an accurate representation of the whole section with IHC analysis in OSCC. Materials and Methods: Twenty tissue samples stained with anti-p53 antibody were scanned at 40x magnification. Three to six virtual cores of size $0.6 \mathrm{~mm}, 1.0 \mathrm{~mm}$ and $1.5 \mathrm{~mm}$ were drawn on the scanned slides. H-scores were obtained for both whole sections and cores using NuclearQuant (3DHistech, Budapest, Hungary) software after eliminating non-tumour cells and artifacts manually. The correspondence between the cores and whole sections were calculated using intra-class correlation and one sample t-test. Results: Good correlation was obtained with just a single core of $0.6 \mathrm{~mm}$ (0.826). Subsequent increase in core number and size resulted in improved correlation coefficient and smaller confidence interval. Conclusion: Three TMA cores of $0.6 \mathrm{~mm}$ would be the most optimal, as not only was there very strong correlation with the whole tissue section, the extra core will also be able to act as confirmation if the results of the first 2 cores are in doubt.

Keywords: Tissue microarray, immunohisto-chemical analysis, oral squamous cell carcinoma, p53 tumor marker, oral cancer.

\section{INTRODUCTION}

Oral cancer (OC) is the $6^{\text {th }}$ most common cancers in the world (1). In Malaysia, the National Cancer Registry Report 2007 reported that OC ranked $16^{\text {th }}$ and $17^{\text {th }}$ most common cancer among females and males in Peninsular Malaysia. The Indian population is most susceptible to OC and it ranks as the $4^{\text {th }}$ most common cancer among Indian females and $8^{\text {th }}$ most common among Indian males (2).

\section{Original Article}

\author{
Ramanathan $A^{1,2}$, Chong $R M^{1}$, Tay $Z W^{1}$, Siow-Wee \\ $C^{3}$, Kallarakkal $T G^{1,2}$, Kassim $N L A^{4}$ \\ ${ }^{1}$ Department of Oro-Maxillofacial Surgical and \\ Medical Science, Faculty of Dentistry, University \\ of Malaya, \\ ${ }^{2}$ Oral Cancer Research and Coordinating Centre, \\ Faculty of Dentistry, University of Malaya, \\ ${ }^{3}$ Bioinformatics and Computational Biology, \\ Institute of Biological Science, Faculty of Science, \\ University of Malaya, 50603 Kuala Lumpur, \\ Malaysia. \\ ${ }^{4}$ Centre for Languages and Pre-University \\ Academic Development, International Islamic \\ University Malaysia 50728 Kuala Lumpur, \\ Malaysia
}

Corresponding Author:

Dr. Anand Ramanathan

Email:drranand@um.edu.my

Oral squamous cell carcinoma (OSCC) accounts for over $90 \%$ of OC cases.

The carcinogenesis of OSSC is still not well understood and over the years, a lot of research has been carried out. One of the most widely used research method is immunohistochemical (IHC) analysis of the cancer cells. Immunohistochemistry refers to the process of detecting antigens in cells by using antibodies that bind specifically to the intended antigen (3). This principle has been known since the 1930s but it was not until 1942 that the first IHC study was reported. Coons et al (1942) used Fluorescein Isothiocyanate (FITC) antibodies to identify Pneumococcal antigens in infected tissue (4). Since then, improvements and refinements have been made in this field and it is now used as a routine diagnostic tool in most laboratories and also widely used in research.

P53 is a tumor suppressor protein, which in humans, is coded by the TP53gene (5). In healthy humans, the p53 protein is continually produced and degraded in the cell. However, mutant p53 proteins which often manifests in cancer are unregulated and not degraded as normal p53 proteins and are thus able to accumulate at very high 
concentrations (6). The p53 protein marker binds to the expressed protein in the amount corresponding to the extent of expression.

The gold standard for tumor research is whole tissue staining. By this method, the whole specimen is stained and analyzed. The result is a totally accurate representation of the tumor that is in question. This is acceptable for most tumors that have large areas to be experimented on. However, in the case of small tumors such as OSCC, there is limited tissue which can be used for research, hence the need for tissue conserving methods that optimize the usage of available oral tissues. Tissue Microarray (TMA) for sample preparation is one such technique.

The concept of TMA was first described by Battifora in 1986 as a 'sausage' method for laboratory tests of large samples (7). However, the current shape of TMA was defined by Kononen et al in 1998 when he described a single paraffin block containing around 1000 different yet uniformly-sized tissue samples. These blocks then produced many slides for experimentation (8).

The advantage of TMA is that multiple tissue samples can be stained and analyzed at the same time. This reduces laboratory errors as well as observer bias as the process is done at the same time to all the tissue specimens (9). Furthermore, the efficiency is also maximized in that a few slides can generate the amount of data that will conventionally require hundreds of slides to obtain. Most of the conventional stain and reagents can be used on TMA cores as with the conventional whole sections (10). As fewer slides are required to produce the data; reagents, tissue and time are dramatically reduced. This technique has successfully been used to develop institution-specific staining profiles for various antibodies as quality assurance analysis (11).

However, the number of cores to be used is controversial especially in tumors that exhibit a high degree of heterogeneity such as OSCC. It is of concern that TMA cores will not fully represent the whole section (12). Many studies have tried to address this issue in regard to other cancers that exhibit high heterogeneity. Camp et al (2000) suggested two $0.6 \mathrm{~mm}$ cores were sufficient in representing the whole section when studying breast carcinoma (13). However, Torhorst et al (2001) and Zhang et al (2003) found that a single core of $0.6 \mathrm{~mm}$ was sufficient $(14,15)$. Hoos et al (2001) studied various fibroblastic tumors and recommended three $0.6 \mathrm{~mm}$ cores to achieve a 96-98\% concordance (16). Similar results were observed by Fernebro et al (2002) when studying rectal cancer (17) and by Proverbs-Singh et al (2001) in prostate cancer (18). Nocito et al (2001) observed that four $0.6 \mathrm{~mm}$ cores were extremely concordant with the whole section in bladder cancer (19). Griffin et al (2003) used p53 immunostaining on squamous cell carcinoma of the larynx to validated TMA (20). With regards to OSCC, Monteiro et al (2010) conducted a study validating this technique and found that two $1.5 \mathrm{~mm}$ cores adequately represented the whole sections (21). However, no further studies were found relating to this topic. Therefore in this study we aim to determine the optimal number of TMA cores required to provide an accurate representation of whole sections with IHC analysis of OSCC by using virtual TMA cores.

\section{MATERIALS AND METHOD}

\section{Tissue samples:}

Twenty samples of OSCC tissues which were stained with anti-p53 antibody were selected for this study. These tissues were obtained from a previous study (22). These samples were scanned using the Pannoramic Desk Scanner (3DHistech, Budapest, Hungary) with magnification of 40x (Figure 1).

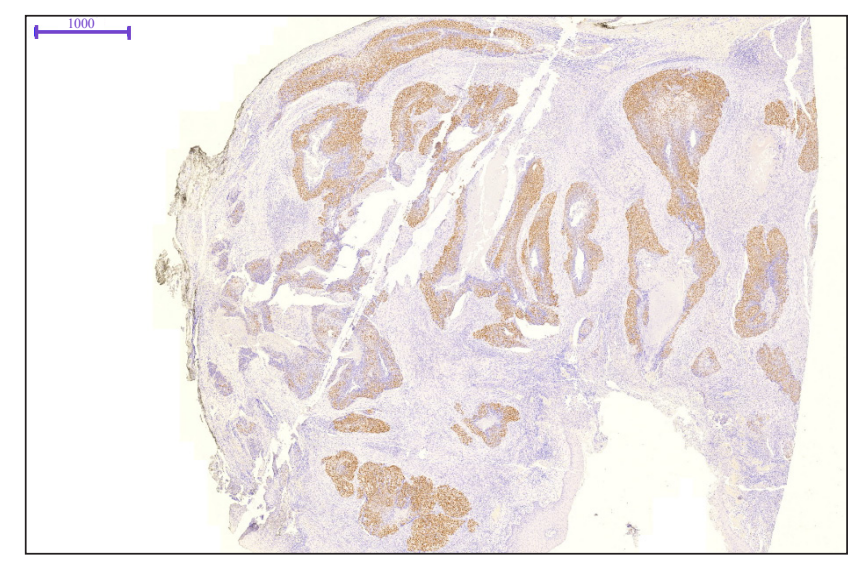

Figure 1: Photomicrograph of OSCC tissue stained with anti-p53 antibody and scanned using Pannoramic Desk Scanner (3DHistech, Budapest, Hungary) (Magnification 4x)

\section{Tissue Microarray:}

On each of the tissue samples, virtual cores of 3 sizes were drawn. The sizes are $0.6 \mathrm{~mm}, 1.0 \mathrm{~mm}$ and $1.5 \mathrm{~mm}$ in diameter. The number of cores ranged from 3 to 6 cores depending on the size of the tissue sample (Figure 2). Before placing the cores, the area of interest were pre-selected to include tumor areas and the same was confirmed by an Oral Pathologist (AR).

The tumor cells were scored according to their intensity of staining as 0 (negative), +1 (weakly positive), +2 (moderately positive) and +3 (strong positive) by using the NuclearQuant (3DHistech, Budapest, Hungary) software (Figure 3). This software isolated the nucleus of each cell and places them in a gallery (Figure 3) for easy scoring which was followed by manual scoring of each cell to obtain the final score. During the process of manual scoring non-tumor cells such as the inflammatory cells, fibroblasts and artifacts were identified and deleted from the gallery. 


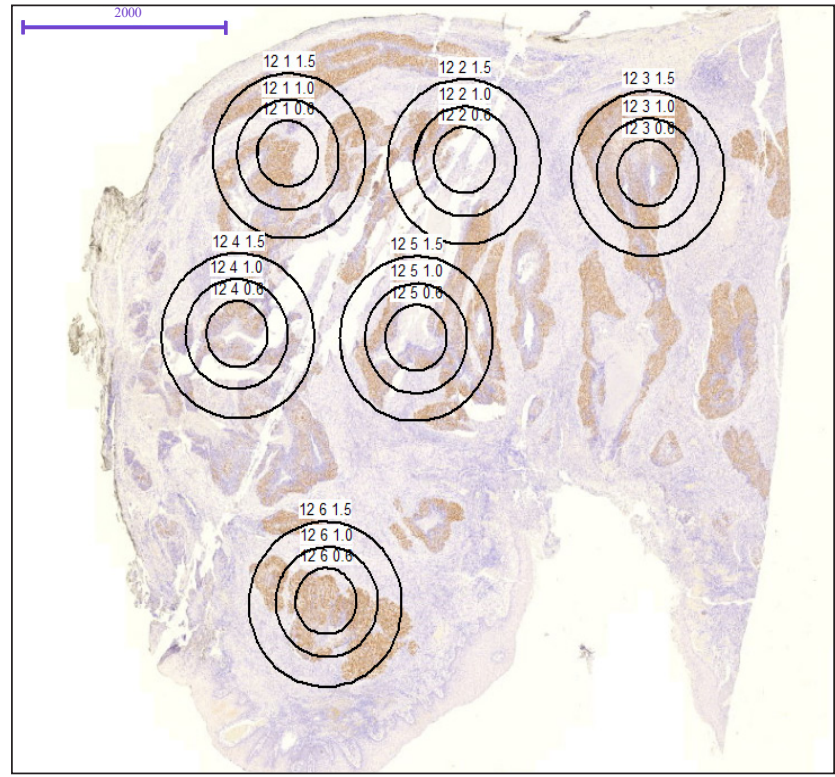

Figure 2: Photomicrograph showing 6 cores of 3 different sizes $(0.6 \mathrm{~mm}, 1.0 \mathrm{~mm}$ and $1.5 \mathrm{~mm}$ in diameter) drawn on the OSCC whole tissue sample (Magnification 4x)

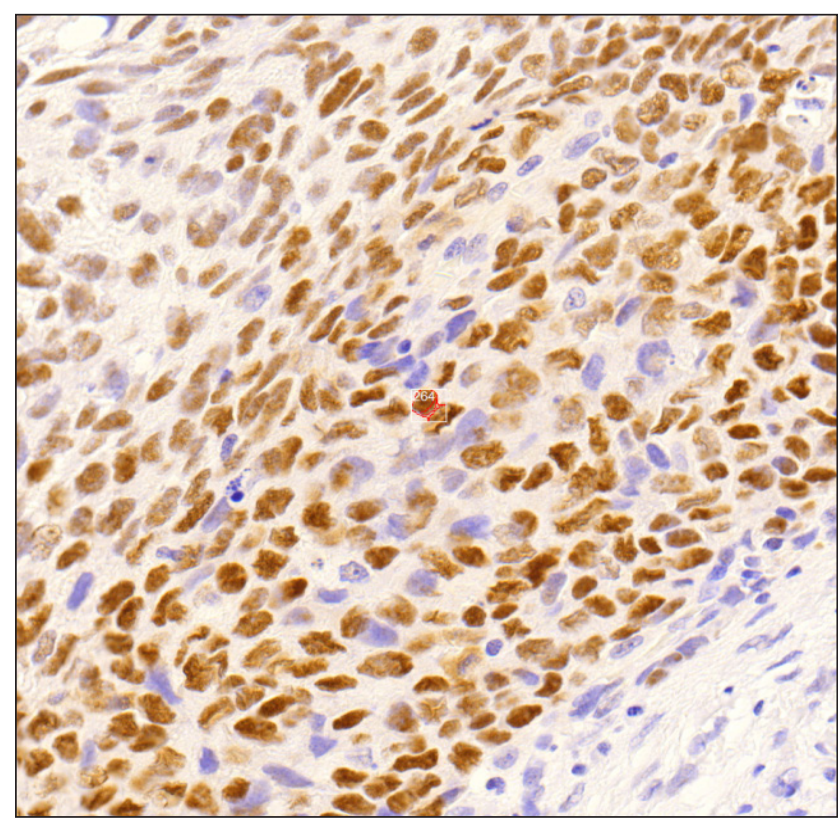

Figure 3: Photomicrograph showing isolation of nuclei and initial scoring with NuclearQuant (3DHistech, Budapest, Hungary) according to staining intensity

The analysis of the whole tissue section was performed and the area of interest, which is the tumor areas were marked out and the procedure was repeated (Figure 4). The NuclearQuant (3DHistech, Budapest, Hungary) software was first used to isolate the cells' nucleus followed by the manual scoring and elimination of the non-tumor cells and artifacts. The H-score, which is a semi-quantitative method of assessing the extent of nuclear immunoreactivity, for each core and the whole tissue section were calculated using the NuclearQuant (3DHistech, Budapest, Hungary) software. The H-score was calculated using the following formula:

$\mathrm{H}$-Score $=(\%$ at 0$) * 0+(\%$ at $1+) * 1+(\%$ at $2+) * 2+$ $(\%$ at $3+) * 3$.

\section{STATISTICAL ANALYSIS}

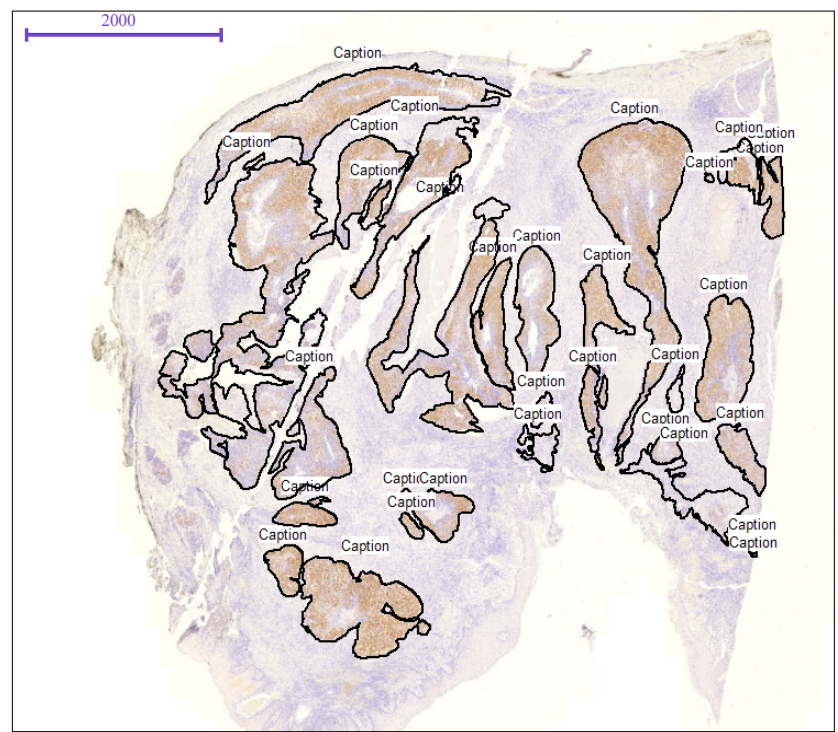

Figure 4: Photomicrograph of whole tissue section of OSCC showing the tumor areas marked (Magnification 4x)

The results were analyzed using SPSS version 20. The $\mathrm{H}$-scores as well as the number of positive and negatively stained cells for each core and the whole tissue section were recorded. The mean H-scores for two, three, four, five, and six cores for all three sizes $(0.6 \mathrm{~mm}, 1.0 \mathrm{~mm}$, and $1.5 \mathrm{~mm}$ ) were calculated. Using those values, the concordance between the TMA core samples and the whole tissue sections were calculated using one sample $\mathrm{t}$-test and intra-class correlation with the $\mathrm{H}$-score as the measurement unit.

\section{RESULTS}

Out of the 20 tissue samples that were scanned in this study, 13 samples were large enough to contain 6 TMA cores. The others were excluded from the study for uniformity. The results are as shown. Supplementary Tables 1, 2, and 3 are provided showing the mean $\mathrm{H}$-score obtained from the TMA cores of all 3 sizes and whole section.

It was observed from the intra-class correlation statistical analysis (Table 1), that a single core of $0.6 \mathrm{~mm}$ diameter sufficiently represents the whole tissue section with a coefficient of 0.828 . However, it is noted that with 
the increase in the number of cores used, the correlation coefficient improved. When two, three, four, five and six cores of $0.6 \mathrm{~mm}$ diameter were used, correlation coefficients of $0.898,0.939,0.959,0.958$, and 0.957 were obtained respectively. Similar patterns of results were seen when cores of sizes $1.0 \mathrm{~mm}$ and $1.5 \mathrm{~mm}$ were used. One core of $1.5 \mathrm{~mm}$ diameter showed a correlation coefficient of 0.860 whereas six cores of $1.5 \mathrm{~mm}$ diameter gave a higher correlation of 0.963 .

The increase in size of the cores also gives a stronger association. With one core of $0.6 \mathrm{~mm}$ diameter, a correlation of 0.828 is attained as opposed to one core of $1.5 \mathrm{~mm}$ diameter which gives a correlation of 0.860 between the TMA core and the whole section.

Table 1: The intraclass correlation between the whole tissue sections (WS) and TMA cores of different sizes (0.6 mm, 1.0 $\mathrm{mm}$ and $1.5 \mathrm{~mm}$ )

\begin{tabular}{|c|c|c|c|c|c|c|}
\hline & \multicolumn{6}{|c|}{ Whole Sections Vs. $0.6 \mathrm{~mm}$ cores } \\
\hline & $\begin{array}{l}1 \text { core } \\
(n=13)\end{array}$ & $\begin{array}{l}2 \text { cores } \\
(n=13)\end{array}$ & $\begin{array}{l}3 \text { cores } \\
(n=13)\end{array}$ & $\begin{array}{l}4 \text { cores } \\
(n=13)\end{array}$ & $\begin{array}{l}5 \text { cores } \\
(n=13)\end{array}$ & $\begin{array}{l}6 \text { cores } \\
(n=13)\end{array}$ \\
\hline $\begin{array}{l}\text { Correlation } \\
\text { Coefficient }\end{array}$ & 0.828 & 0.898 & 0.939 & 0.959 & 0.958 & 0.957 \\
\hline p-value & 0.002 & 0.000 & 0.000 & 0.000 & 0.000 & 0.000 \\
\hline \multirow[t]{2}{*}{$\begin{array}{l}\text { 95\% Confidence } \\
\text { Interval }\end{array}$} & $0.435-0.947$ & $0.666-0.969$ & $0.799-0.981$ & $0.864-0.987$ & $0.863-0.987$ & $0.857-0.987$ \\
\hline & \multicolumn{6}{|c|}{ Whole Sections Vs. $1.0 \mathrm{~mm}$ cores } \\
\hline $\begin{array}{l}\text { Correlation } \\
\text { Coefficient }\end{array}$ & 0.818 & 0.891 & 0.926 & 0.866 & 0.955 & 0.955 \\
\hline p-value & 0.003 & 0.000 & 0.000 & 0.001 & 0.000 & 0.000 \\
\hline \multirow[t]{2}{*}{$\begin{array}{l}\text { 95\% Confidence } \\
\text { Interval }\end{array}$} & $0.405-0.945$ & $0.644-0.967$ & $0.759-0.978$ & $0.516-0.959$ & $0.853-0.986$ & 0.853-0.986 \\
\hline & \multicolumn{6}{|c|}{ Whole Sections Vs. $1.5 \mathrm{~mm}$ cores } \\
\hline $\begin{array}{l}\text { Correlation } \\
\text { Coefficient }\end{array}$ & 0.860 & 0.901 & 0.939 & 0.952 & 0.959 & 0.963 \\
\hline p-value & 0.001 & 0.000 & 0.000 & 0.000 & 0.000 & 0.000 \\
\hline $\begin{array}{l}\text { 095\% Confidence } \\
\text { Interval }\end{array}$ & $0.540-0.957$ & $0.674-0.970$ & $0.800-0.981$ & $0.841-0.985$ & $0.867-0.988$ & $0.878-0.989$ \\
\hline
\end{tabular}

Furthermore, as the number of the TMA cores increases, the range of the $95 \%$ confidence interval (CI) becomes smaller. When only one core of $0.6 \mathrm{~mm}$ diameter is used, the $95 \%$ CI ranges from 0.51 whereas, with 6 cores, a 95\% CI from 0.13 is achieved. Similar patterns were also observed when cores of size $1.0 \mathrm{~mm}$ and $1.5 \mathrm{~mm}$ diameters were used. The $95 \%$ CI becomes smaller with the increase in the size of the core from $0.6 \mathrm{~mm}$ to $1.5 \mathrm{~mm}$ diameters.
One sample t-test (Table 2), also demonstrates good concordance between a single core of the TMA and whole sections. P-value of $>0.05$ were obtained with just one core of different sizes $(0.6 \mathrm{~mm}, 1.0 \mathrm{~mm}$ and $1.5 \mathrm{~mm})$ signifying that there is no significant difference between one core and the whole section.

Table 2: $p$-values of one sample t-test between the whole tissue sections (WS) and TMA cores of different sizes (0.6 mm, $1.0 \mathrm{~mm}$ and $1.5 \mathrm{~mm}$ )

\begin{tabular}{|c|c|c|c|c|c|c|}
\hline & $\mathbf{1}$ core & $\mathbf{2}$ cores & $\mathbf{3}$ cores & $\mathbf{4}$ cores & 5 cores & $\mathbf{6}$ cores \\
\hline Whole Sections Vs. $\mathbf{0 . 6} \mathbf{~ m m ~ c o r e s ~}$ & 0.825 & 0.787 & 0.891 & 0.895 & 0.672 & 0.736 \\
\hline Whole Sections Vs. 1.0 $\mathbf{~ m m ~ c o r e s ~}$ & 0.758 & 0.789 & 0.817 & 0.593 & 0.895 & 0.823 \\
\hline Whole Sections Vs. $1.5 \mathbf{m m}$ cores & 0.784 & 0.840 & 0.972 & 0.768 & 0.928 & 0.995 \\
\hline
\end{tabular}


Supplementary Table 1: The mean H-scores for $0.6 \mathrm{~mm}$ TMA cores and the whole sections for 20 samples

\begin{tabular}{|c|c|c|c|c|c|c|c|c|c|}
\hline Slide & Size & $\begin{array}{c}\text { Sample } \\
\text { No. }\end{array}$ & Six Cores & Five Cores & Four Cores & Three Cores & Two Cores & One Core & $\begin{array}{c}\text { Whole } \\
\text { Section }\end{array}$ \\
\hline tma a1-2 & $0.6 \mathrm{~mm}$ & 1 & 161.535 & 160.842 & 168.9801 & 160.1311 & 175.4477 & 194.8953 & 191.0037 \\
\hline tma a1-2 & $0.6 \mathrm{~mm}$ & 2 & 78.2946 & 77.6572 & 82.5796 & 86.4885 & 95.847 & 116.16 & 32.528 \\
\hline tma a1-5 & $0.6 \mathrm{~mm}$ & 3 & & & & 8.6097 & 6.0786 & 3.4298 & 176.0478 \\
\hline tma a1-3 & $0.6 \mathrm{~mm}$ & 4 & & & & 40.215 & 29.934 & 29.5181 & 116.1594 \\
\hline tma a1-4 & $0.6 \mathrm{~mm}$ & 5 & 97.9584 & 79.2659 & 94.7871 & 123.1935 & 180.0722 & 207.5758 & 50.39 \\
\hline tma a1-5 & $0.6 \mathrm{~mm}$ & 6 & & & 192.4487 & 180.4001 & 178.8325 & 162.4595 & 21.361 \\
\hline tma a1-7 & $0.6 \mathrm{~mm}$ & 7 & 75.7081 & 72.5179 & 66.2334 & 64.4829 & 61.9088 & 61.2216 & 77.0994 \\
\hline tma a1-8 & $0.6 \mathrm{~mm}$ & 8 & 149.6573 & 149.732 & 148.8029 & 148.3364 & 158.8472 & 215.7895 & 104.4944 \\
\hline tma a2-7 & $0.6 \mathrm{~mm}$ & 9 & & & 211.8551 & 209.8587 & 201.9382 & 226.1137 & 185.7361 \\
\hline tma a2-9 & $0.6 \mathrm{~mm}$ & 10 & & & & 18.6495 & 24.4217 & 29.1332 & 25.1934 \\
\hline tma a1-3 & $0.6 \mathrm{~mm}$ & 11 & & & & 40.2149 & 9.934 & 29.5181 & 17.9218 \\
\hline tma a8-3 & $0.6 \mathrm{~mm}$ & 12 & 207.4795 & 206.7077 & 212.3231 & 214.5001 & 199.5934 & 230.5019 & 191.2527 \\
\hline tma a8-3 & $0.6 \mathrm{~mm}$ & 13 & 219.112 & 221.8273 & 222.3188 & 223.5856 & 201.4623 & 152.2222 & 143.0293 \\
\hline tma a8-3 & $0.6 \mathrm{~mm}$ & 14 & 256.4484 & 258.2212 & 250.1004 & 241.4984 & 237.0382 & 269.2063 & 214.2186 \\
\hline tma a8-5 & $0.6 \mathrm{~mm}$ & 15 & 20.7531 & 23.6778 & 20.1593 & 13.1311 & 14.216 & 20.4276 & 13.4525 \\
\hline tma a3-3 & $0.6 \mathrm{~mm}$ & 16 & 81.2919 & 81.0418 & 91.5753 & 94.0831 & 111.4679 & 146.384 & 73.0539 \\
\hline tma a3-3 & $0.6 \mathrm{~mm}$ & 17 & 71.8919 & 70.2771 & 77.8054 & 91.0898 & 96.8234 & 124.1176 & 44.8392 \\
\hline tma a4-4 & $0.6 \mathrm{~mm}$ & 18 & 166.6509 & 158.4107 & 139.1714 & 142.9095 & 138.2181 & 88.853 & 115.9934 \\
\hline tma a4-4 & $0.6 \mathrm{~mm}$ & 19 & 93.7849 & 93.2284 & 100.943 & 101.2573 & 106.886 & 106.9252 & 55.8668 \\
\hline tma a1-2 & $0.6 \mathrm{~mm}$ & 20 & & & & 83.9428 & 90.0672 & 77.0093 & 1.5789 \\
\hline
\end{tabular}

Supplementary Table 2: The mean H-scores for $1.0 \mathrm{~mm}$ TMA cores and the whole sections for 20 samples

\begin{tabular}{|c|c|c|c|c|c|c|c|c|c|}
\hline Slide & Size & $\begin{array}{c}\text { Sample } \\
\text { No. }\end{array}$ & $\begin{array}{c}\text { Six } \\
\text { Cores }\end{array}$ & $\begin{array}{c}\text { Five } \\
\text { Cores }\end{array}$ & $\begin{array}{c}\text { Four } \\
\text { Cores }\end{array}$ & $\begin{array}{c}\text { Three } \\
\text { Cores }\end{array}$ & $\begin{array}{c}\text { Two } \\
\text { Cores }\end{array}$ & $\begin{array}{c}\text { One } \\
\text { core }\end{array}$ & $\begin{array}{c}\text { Whole } \\
\text { Section }\end{array}$ \\
\hline tma a1-2 & $1.0 \mathrm{~mm}$ & 1 & 155.6665 & 152.5979 & 156.4935 & 144.0588 & 155.7493 & 155.2707 & 191.0037 \\
\hline tma a1-2 & $1.0 \mathrm{~mm}$ & 2 & 79.8836 & 81.0064 & 84.4664 & 90.3637 & 95.5575 & 114.023 & 32.528 \\
\hline tma a1-5 & $1.0 \mathrm{~mm}$ & 3 & & & & 7.8144 & 6.4743 & 5.7848 & 176.0478 \\
\hline tma a1-3 & $1.0 \mathrm{~mm}$ & 4 & & & & 22.0137 & 23.0205 & 24.3386 & 116.1594 \\
\hline tma a1-4 & $1.0 \mathrm{~mm}$ & 5 & 92.1232 & 71.7371 & 87.1421 & 113.3378 & 166.132 & 208.8677 & 50.39 \\
\hline tma a1-5 & $1.0 \mathrm{~mm}$ & 6 & & & 189.9537 & 182.9382 & 182.9514 & 167.754 & 21.361 \\
\hline tma a1-7 & $1.0 \mathrm{~mm}$ & 7 & 72.2262 & 68.9667 & 67.4923 & 63.7773 & 56.0723 & 56.9721 & 77.0994 \\
\hline tma a1-8 & $1.0 \mathrm{~mm}$ & 8 & 92.5682 & 97.2357 & 100.5648 & 106.3989 & 119.4488 & 162.3106 & 104.4944 \\
\hline tma a2-7 & $1.0 \mathrm{~mm}$ & 9 & & & 231.018 & 228.8279 & 223.4436 & 238.6425 & 185.7361 \\
\hline tma a2-9 & $1.0 \mathrm{~mm}$ & 10 & & & & 15.9421 & 20.4182 & 23.6264 & 25.1934 \\
\hline tma a1-3 & $1.0 \mathrm{~mm}$ & 11 & & & & 38.2633 & 27.677 & 33.6516 & 17.9218 \\
\hline tma a8-3 & $1.0 \mathrm{~mm}$ & 12 & 213.0542 & 206.0902 & 205.0833 & 216.209 & 197.0585 & 220.1017 & 191.2527 \\
\hline tma a8-3 & $1.0 \mathrm{~mm}$ & 13 & 212.471 & 217.1499 & 20.4725 & 224.5367 & 207.8591 & 214.9533 & 143.0293 \\
\hline tma a8-3 & $1.0 \mathrm{~mm}$ & 14 & 254.1115 & 251.5934 & 246.6363 & 242.8242 & 240.4987 & 264.5409 & 214.2186 \\
\hline tma a8-5 & $1.0 \mathrm{~mm}$ & 15 & 24.3222 & 27.0573 & 23.7146 & 16.8091 & 14.6904 & 21.2312 & 13.4525 \\
\hline tma a3-3 & $1.0 \mathrm{~mm}$ & 16 & 80.431 & 80.2345 & 88.5647 & 97.1733 & 98.4907 & 123.7611 & 73.0539 \\
\hline tma a3-3 & $1.0 \mathrm{~mm}$ & 17 & 70.349 & 69.8949 & 74.506 & 77.9585 & 87.7807 & 109.8936 & 44.8392 \\
\hline tma a4-4 & $1.0 \mathrm{~mm}$ & 18 & 150.638 & 135.9344 & 116.7212 & 110.781 & 108.4792 & 73.7399 & 115.9934 \\
\hline tma a4-4 & $1.0 \mathrm{~mm}$ & 19 & 88.1895 & 87.7329 & 96.7179 & 97.4678 & 101.2041 & 97.1 & 55.8668 \\
\hline tma a1-2 & $1.0 \mathrm{~mm}$ & 20 & & & & 77.166 & 84.4406 & 80.8713 & 1.5789 \\
\hline
\end{tabular}


Supplementary Table 3: The mean H-scores for $1.5 \mathrm{~mm}$ TMA cores and the whole sections for 20 samples

\begin{tabular}{|c|c|c|c|c|c|c|c|c|c|}
\hline Slide & Size & $\begin{array}{c}\text { Sample } \\
\text { No. }\end{array}$ & Six Cores & $\begin{array}{c}\text { Five } \\
\text { Cores }\end{array}$ & $\begin{array}{c}\text { Four } \\
\text { Cores }\end{array}$ & $\begin{array}{c}\text { Three } \\
\text { Cores }\end{array}$ & Two Cores & One core & $\begin{array}{c}\text { Whole } \\
\text { Section }\end{array}$ \\
\hline tma a1-2 & $1.5 \mathrm{~mm}$ & 1 & 154.1588 & 150.3473 & 151.3759 & 148.5799 & 159.3927 & 170.6875 & 191.0037 \\
\hline tma a1-2 & $1.5 \mathrm{~mm}$ & 2 & 75.3816 & 75.1898 & 77.1198 & 83.2951 & 85.2682 & 98.0083 & 32.528 \\
\hline tma a1-5 & $1.5 \mathrm{~mm}$ & 3 & & & & 6.4681 & 5.961 & 6.4324 & 176.0478 \\
\hline tma a1-3 & $1.5 \mathrm{~mm}$ & 4 & & & & 37.9623 & 27.2255 & 33.6516 & 116.1594 \\
\hline tma a1-4 & $1.5 \mathrm{~mm}$ & 5 & 86.1948 & 71.8763 & 86.7709 & 11.5157 & 164.5813 & 211.7115 & 50.39 \\
\hline tma a1-5 & $1.5 \mathrm{~mm}$ & 6 & & & 179.7642 & 174.7685 & 180.5876 & 172.2812 & 21.361 \\
\hline tma a1-7 & $1.5 \mathrm{~mm}$ & 7 & 76.0496 & 71.2202 & 63.1582 & 58.963 & 45.1431 & 44.7297 & 77.0994 \\
\hline tma a1-8 & $1.5 \mathrm{~mm}$ & 8 & 90.8068 & 93.1111 & 97.6727 & 102.6193 & 103.8037 & 129.8955 & 104.4944 \\
\hline tma a2-7 & $1.5 \mathrm{~mm}$ & 9 & & & 181.6045 & 164.18 & 144.559 & 194.3501 & 185.7361 \\
\hline tma a2-9 & $1.5 \mathrm{~mm}$ & 10 & & & & 15.9742 & 18.7652 & 23.6008 & 25.1934 \\
\hline tma a1-3 & $1.5 \mathrm{~mm}$ & 11 & & & & 35.8998 & 25.573 & 30.3466 & 17.9218 \\
\hline tma a8-3 & $1.5 \mathrm{~mm}$ & 12 & 208.0691 & 203.9097 & 202.1625 & 218.5194 & 206.5829 & 229.307 & 191.2527 \\
\hline tma a8-3 & $1.5 \mathrm{~mm}$ & 13 & 197.8191 & 204.7383 & 206.5808 & 206.32 & 188.8108 & 216.129 & 143.0293 \\
\hline tma a8-3 & $1.5 \mathrm{~mm}$ & 14 & 250.6079 & 246.5114 & 241.0272 & 238.0932 & 233.7054 & 248.9276 & 214.2186 \\
\hline tma a8-5 & $1.5 \mathrm{~mm}$ & 15 & 25.4611 & 28.1224 & 25.2861 & 17.6418 & 15.5898 & 22.1773 & 13.4525 \\
\hline tma a3-3 & $1.5 \mathrm{~mm}$ & 16 & 80.267 & 80.8588 & 88.8306 & 95.2741 & 95.0777 & 112.5683 & 73.0539 \\
\hline tma a3-3 & $1.5 \mathrm{~mm}$ & 17 & 74.8564 & 75.5114 & 79.0802 & 81.6948 & 87.2221 & 106.0351 & 44.8392 \\
\hline tma a4-4 & $1.5 \mathrm{~mm}$ & 18 & 142.1107 & 125.9181 & 114.7151 & 108.241 & 111.635 & 125.7152 & 115.9934 \\
\hline tma a4-4 & $1.5 \mathrm{~mm}$ & 19 & 86.6074 & 87.452 & 95.8013 & 96.0996 & 99.0087 & 91.8426 & 55.8668 \\
\hline tma a1-2 & $1.5 \mathrm{~mm}$ & 20 & & & & 80.8029 & 88.0045 & 86.1533 & 1.5789 \\
\hline
\end{tabular}

\section{DISCUSSION}

The aim of this study was to find out the optimal number of TMA cores to accurately represent the whole section with IHC analysis in OSCC. The tissue samples were stained with p53 protein marker. In order to assess the immunoreactivity of the cancer cells, H-scores of the cores and whole sections were calculated. This algorithm includes capturing the percentage of tumor cells stained at each intensity level. This score is more representative of the staining of the entire tumor on the section. Although given sections may share the same simple intensity score, there clearly is a difference between a $3+$ case with only $10 \%$ of the cells staining as compared to a $3+$ case where greater than $90 \%$ of the cells are staining. This difference is easily picked up using H-Score method. An H-Score is typically calculated for staining of each sub-cellular compartment for both normal and tumor cells using the following formula; $\mathrm{H}-\mathrm{Score}=(\%$ at 0$) \times 0+(\%$ at $1+) \times 1$ $+(\%$ at $2+) \times 2+(\%$ at $3+) \times 3$. Thus, this score produces a continuous variable that ranges from 0 to 300 .

In this study, it was observed that from the intraclass correlation and the one sample t-test that one $0.6 \mathrm{~mm}$ core is sufficient to represent the whole section with a correlation of 0.828 . Furthermore, the intra-class correlation shows that increasing the number of cores gives higher levels of association as well as narrower range of $95 \% \mathrm{CI}$. Increasing the size of the cores also yields better concordance between the TMA cores and the whole section. However, as the main purpose of TMA is to conserve the tissue available, it is shown that only one core of $0.6 \mathrm{~mm}$ is adequate to represent the whole tissue section.

However, the problem of tissue loss is a prominent issue in other similar studies which have used constructed TMA blocks. Gulmann et al (2003) reported a loss of 15\% of cores in their study (23). Fernebro et al (2002) and Griffin et al (2003) reported 17\% loss of tissue samples $(17,20)$ whereas Monteiro et al (2010) reported the highest, $19.8 \%$ loss of TMA core samples (21).

Although a single core of $0.6 \mathrm{~mm}$ is sufficient to adequately represent the whole section, when the sample loss is taken into account, it is suggested that minimum of three cores of diameter $0.6 \mathrm{~mm}$ be used. This not only gives a high level of concordance between the TMA and the whole section, it also provides for the event of loss of tissue core. Furthermore, the third core will be able to verify should the first two cores display contradictory results during semi-quantitative scoring.

Normally, TMA cores are constructed from the donor tissue blocks whereas in this study virtual cores were constructed on scanned images of the whole tissue 
section and used for analysis. Hence, this may not represent the occurrence of real-life events when using real TMA cores such as the presence of unusable cores due to loss or folding of the tissue. Therefore, in this study, losses of tissue TMA cores due to unusable cores were not accounted for in the analysis. Moreover, in this study, the virtual TMA cores were selected after immunostaining was performed, from areas that exhibited immunostained cells in the whole section. This might have led to some selections bias whereas, in real-life events using TMA, the cores are selected before immunostaining is performed which may result in selection of areas that may not have the immunostaining. It is suggested that this study be carried out with a larger sample size. This study should also be validated using real TMA cores in order to fully depict the real-life implications where the TMA core losses come into consideration in the results. This study can be further extended to include other markers such as Ki-67, p63 to analyze if there is a need for performing such studies for each marker when using TMA with oral cancer tissues.

\section{CONCLUSION}

Three TMA cores of $0.6 \mathrm{~mm}$ would be the most optimal, as not only is there a very strong correlation with the whole tissue section, the extra core will also be able to act as confirmation if the results of the first 2 cores are in doubt.

\section{ACKNOWLEDGEMENTS}

The authors would like to acknowledge Prof. Rosnah Binti Mohd. Zain for her inputs on preparing this manuscript. We would also like to thank Mrs. Junaida Maimunah Hassan Basari for her help provided with the lab work and 3D Histech, Budapest, Hungary for providing us with the Pannoramic Desk Scanner and the NuclearQuant.

\section{Declaration of conflicts of interest:}

The authors have no conflicts of interest to declare.

\section{REFERENCES}

1. Warnakulasuriya S. Global Epidemiology of oral and oropharyngeal cancer. Oral Oncol. 2009; 45(4): 309-16.

2. Omar ZA, Tamin NSI. National Cancer Registry Report. Malaysia Cancer Statistics-Data and Figure 2007, Ministry of Health, Malaysia. 2011(Feb): 54-5.

3. Ramos-Vara JA. Technical aspects of immunohistochemistry. Vet Pathol. 2005; 42(4): 405-26.

4. Coons AH, Creech HJ, Jone RN, Berliner E. The demonstration of pneumococcal antigen in tissue by use of fluorescent antibodies. J Immunol. 1942; 45 : 159-70. (Cross reference)

5. Isobe M, Emanuel BS, Givol D, Oren M, Croce CM. Localization of gene for human p53 tumour antigen to band 17p13. Nature. 1986;320(6057):84-5. (Cross reference)

6. Bullock AN, Henckel J, DeDecker BS, Johnson CM, Nikolova PV, Proctor MR, Lane DP, Fersht AR. Thermodynamic stability of wild type and mutant p53 core domain. Proc Natl Acad Sci USA. 1997; 94(26): 14338-42.

7. Battifora H. The multitumor (sausage) tissue block: novel method for immunohistochemical antibody testing. Lab Invest. 1986; 55: 244-48. (Cross reference)

8. Kononen J, Bubendorf L, Kallioniemi A, Bärlund M, Schraml P, Leighton S, Torhorst J, Mihatsch MJ, Sauter G, Kallioniemi OP.Tissue microarrays for high-throughput molecular profiling of tumor specimens. Nat Med. 1998; 5: 844-47.

9. Rimm DL, Camp RL, Charette LA, Costa J, Olsen DA, Reiss M. Tissue microarray: a new technology for amplification of tissue resources. Cancer J. 2001; 7: 24-31.

10. Rubin MA, Dunn R, Strawdermann M, Rienta KJ. Tissue microarray sampling strategy for prostate cancer biomarker analysis. Am J Surg Pathol. 2002; 26: 312-9.

11. Milanes-Yearsley M, Hamond EH, Pajak TF, Cooper JS, Chang C, Griffin T, Nelson D, Laramore G, Pilepich M. Tissue microarray: a cost and time effective method for correlative studies by regional and national cancer study groups. Mod Pathol. 2002; 15: 1366-73.

12. Skacel M, Hicks DG, Tubbs RR. Tissue Microarrays and Their Modifications in High-Throughput Analysis of Clinical Specimens. Handbook of Immunohistochemistry and in-situ Hybridization of Human Carcinomas. 2004; 1: 57-65.

13. Camp RL, Charette LA, Rimm DL. Validation of tissue microarray technology in breast carcinoma. Lab Invest. 2000; 80: 1943-49.

14. Tohorst J, Bucher C, Kononen J, Haas P, Zuber M, Kochli OR, Mross F, Dietrich H, Moch H, Mihatch MJ, Kallioniemi OP, Sauter G. Tissue microarrays for rapid linking of molecular changes to clinical endpoints. Am J Pathol. 2001; 159: 2249-56.

15. Zhang D, Salto-Tellez M, Putti TC, Do E, Koay ES. Reliability of tissue microarrays in detecting protein expression and gene amplification in breast cancer. Mod Pathol. 2003; 16: 79-85.

16. Hoos A, Urist MJ, Stojadinovic A, Mastorides S, Dudas ME, Leung DHY, Kuo D, Brennen MF, Lewis JJ, Cordon-Cardo C. Validation of Tissue 
Microarrays for Immunohistochemical Profiling of Cancer Specimens Using the Example of Human Fibroblastic Tumors. Am J Pathol. 2001; 158: 124551.

17. Fernebro E, Dictor M, Bendhal P, Ferno M, Nilbert M. Evaluation of the tissue microarray technique for immunohistochemical analysis in rectal cancer. Arch Pathol Lab Med. 2002; 126: 702-5.

18. Proverbs-Singh T, Mucci NR, Strawdermann M, Rubin MA. Prostate carcinoma biomarker analysis using tissue microarrays: Optimization of a tissue sampling strategy for proliferation labeling index. Mod Pathol. 2001; 14: 117A (Abstract)

19. Nocito A, Bubendorf L, Tinner ME, Suess K, Wagner U, Forster T, Kononen J, Fijan A, Bruderer J, Schmid U, Ackerman D, Maurer R, Alund G, Knonagel H, Rist M, Anabitarte M, Hering F, Hardmeier T, Schonenberger A, Flury R, Jager P, Fher LJ, Schraml P. Moch H, Mihatch MJ, Gasser
T, Sauter G. Microarrays of bladder cancer tissue are highly representative of proliferative index and histological grade. J. Pathol. 2001; 194: 349-57.

20. Griffin MC, Robinson RA, Trask DK. Validation of tissue microarrays using p53 immunohistochemical studies of squamous cell carcinoma of the larynx. Mod Pathol. 2003; 16(12): 1181-88.

21. Monteiro LS, Diniz-Freitas M, Garcia-Caballero T, Forteza J, Fraga M. EGFR and Ki-67 expression in oral squamous cell carcinoma using tissue microarray technology. J Oral Pathol Med. 2010; 39: 571-78.

22. Siow-Wee C, Abdul-Kareem S, Kallarakkal TG, Merican AF, Abraham MT, Zain RB. Feature Selection Methods for Optimizing Input Variables in Oral Cancer Prognosis. APJCP. 2011; 12: 2659-64.

23. Gulmann C, O'Grady A. Tissue microarrays: an overview. Current Diagnostic Pathology. 2003; 9: 149-54. 